\title{
Faktor-faktor yang Memengaruhi terjadinya Komplikasi pada Anak dengan Infeksi Dengue di Rumah Sakit Umum Daerah Abdul Wahab Sjahranie Samarinda
}

Regita Pratiwi, ${ }^{1}$ Yuniati, ${ }^{2}$ Muhammad Buchori ${ }^{3}$

${ }^{1}$ Program Studi Kedokteran, ${ }^{2}$ Laboratorium Mikrobiologi, ${ }^{3}$ Laboratorium Ilmu Kesehatan Anak Fakultas Kedokteran Universitas Mulawarman, Samarinda

Latar belakang. Infeksi dengue memiliki tiga fase. Fase kritis yang tidak dapat dilewati dengan baik dapat menyebabkan perburukan keadaan dan komplikasi. Pemeriksaan fisik dan laboratorium merupakan pemeriksaan rutin. Status gizi, nilai trombosit dan hematokrit dapat membantu prediksi perburukan keadaan berupa komplikasi pada pasien anak dengan infeksi dengue.

Tujuan. Untuk mengetahui hubungan antara status gizi, nilai trombosit dan kadar hematokrit dengan kejadian komplikasi pada anak dengan infeksi dengue.

Metode. Penelitian analitik observasional dengan desain cross sectional. Data diambil dari rekam medik di RSUD Abdul Wahab Sjahranie Samarinda dengan menggunakan teknik purposive sampling dari bulan Februari-Maret 2020. Analisis statistik menggunakan uji Fisher exact dan Kruskal Wallis test, kemaknaan ditentukan berdasarkan nilai $\mathrm{p}<0,05$.

Hasil. Didapatkan sebanyak 110 sampel, dengan rincian 36 sampel mengalami komplikasi dan 74 sampel tidak mengalami komplikasi. Nilai signifikansi yang didapatkan dari analisis data adalah status gizi $\mathrm{p}=0,036(\mathrm{p}<0,05$, OR 2,39), nilai trombosit $\mathrm{p}=0,001 \quad(\mathrm{p}<0,05, \mathrm{OR} 6,09)$, dan kadar hematokrit $\mathrm{p}=0,010$ ( $\mathrm{p}<0,05$ OR 2,48).

Kesimpulan. Status gizi, nilai trombosit dan kadar hematokrit berhubungan dengan terjadinya komplikasi pada anak dengan infeksi dengue. Sari Pediatri 2021;23(4):242-6

Kata kunci: infeksi dengue anak, komplikasi, status gizi, nilai trombosit, kadar hematokrit

\section{Factors that Influencing Complications in Children with Dengue Infection at RSUD Abdul Wahab Sjahranie Samarinda}

Regita Pratiwi, ${ }^{1}$ Yuniati, ${ }^{2}$ Muhammad Buchori ${ }^{3}$

Background. Dengue infection has three phases. The complication and worsening situations could be found if cannot pass the critical phase properly. Physical and laboratory examinations were routine examinations. Nutritional status, platelets count and hematocrit could help to predict worsening conditions in the form of complications in children with dengue infection.

Objective. To find the correlation of nutritional status, platelets count, and hematocrit with the occurrence of complications in children with dengue infection.

Methods. We conducted a retrospective study with cross sectional design. The sample was taken from medical records at Abdul Wahab Sjahranie Hospital in Samarinda using purposive sampling technique from February-March 2020. Statistical analysis using Fisher exact test and Kruskal Wallis test, the significance was determined based on p value $<0.05$.

Result. Of 110 samples, 36 samples had complications and 74 samples didnot. Significance values obtained from analysis were nutritional status $\mathrm{p}=0,036(\mathrm{p}<0,05)$, platelets count $\mathrm{p}=0,001(\mathrm{p}<0,05)$, and hematocrit $\mathrm{p}=0,010(\mathrm{p}<0,05)$.

Conclusion. nutritional status, platelets count, and hematocrit could influence complications in children with dengue infection. Sari Pediatri 2021;23(4):242-6

Keywords: dengue infection in children, complications, nutritional status, platelets count, hematocrit

Alamat korespondensi: Regita Pratiwi. Program Studi Kedokteran Fakultas Kedokteran Universitas Mulawarman. Jl. Krayan, Kampus Gn. Kelua, Samarinda 75123. Email : regitapratiwi.gita@gmail.com 
Regita Pratiwi dkk: Faktor-faktor yang memengaruhi terjadinya komplikasi pada anak dengan infeksi dengue

$\mathrm{V}$ irus dengue termasuk group B arthropod virus (arboviruses) dan sekarang dikenal sebagai genus flavivirus, keluarga Flaviviridae yang menginfeksi manusia melalui gigitan nyamuk. ${ }^{1,2}$ World Health Organization pada tahun 2019 menetapkan infeksi dengue merupakan salah satu dari 10 ancaman kesehatan global, diperkirakan terdapat 40\% populasi dunia yang berisiko terkena infeksi dengue. ${ }^{3}$

Pada tahun 2020, WHO melaporkan bahwa saat ini Asia dan Amerika Latin merupakan negara dengan angka infeksi dengue berat tertinggi di dunia, baik pada pasien dewasa maupun anak. ${ }^{4}$ Case fatality rate (CFR) atau angka kematian pasien yang terinfeksi dengue di Amerika pada tahun 2019 sebanyak 0,05\%, sedangkan data salah satu RS swasta di Indonesia menyebutkan 29\% dari keseluruhan pasien anak yang terinfeksi dengue mengalami infeksi dengue derajat III dan derajat IV, $5,71 \%$ di antaranya meninggal dalam masa perawatan.,

Incidence rate (IR) atau angka kejadian infeksi dengue di Indonesia sejak tahun 2012 hingga 2015 memperlihatkan Kalimantan Timur selalu berada dalam posisi lima besar dengan IR tertinggi di Indonesia. ${ }^{8}$ Data dari Dinas Kesehatan Kalimantan Timur (2018) dari tahun 2013 hingga 2016 jumlah kasus infeksi dengue selalu mengalami peningkatan tiap tahunnya. Tahun 2017 tercatat 1.734 kasus dan Samarinda berada di posisi pertama dengan 519 kasus. ${ }^{9}$

Badan kesehatan dunia WHO (2012) menyebutkan terdapat tiga fase dalam infeksi dengue. Fase kritis yang gagal dilalui pasien dapat menyebabkan perburukan keadaan, komplikasi yang memberikan dampak ke organ lain, serta yang paling buruk adalah kematian. ${ }^{7}$

Komplikasi pada infeksi dengue adalah ensefalopati dan kelainan hati, sedangkan pada bayi yang terbanyak ditemukan adalah efusi pleura, hipoalbuminemia, hiponatremia, gangguan liver, serta hipokalsemia. ${ }^{10,11}$ Komplikasi dapat disebabkan oleh banyak faktor. Pasien dengan status gizi kurang berisiko lebih besar mengalami infeksi dengue dengan tingkat keparahan yang lebih tinggi dibanding pasien dengan status gizi normal. ${ }^{12,13}$ Berdasarkan pemeriksaan status hematologi, kadar trombosit $\leq 50.000 / \mathrm{uL}$ dan hematokrit $>45 \%$ dapat menyebabkan perburukan keadaan dan yang terparah adalah komplikasi berupa syok. ${ }^{14}$

Rumah Sakit Umum Daerah Abdul Wahab Sjahranie Samarinda mencatat infeksi dengue berada pada posisi pertama dalam sepuluh penyakit tebanyak rawat inap dengan jumlah kasus 1059 kasus di tahun
2016. ${ }^{15}$ Berdasarkan prevalensi infeksi dengue yang telah diuraikan sebelumnya, baik di Indonesia maupun Kalimantan Timur sendiri terlihat kasus infeksi dengue masih tinggi. Angka kejadian tersebut memungkinkan terdapat banyak kasus komplikasi. Penelitian sebelumnya belum ada yang mencari hubungan antara beberapa faktor dengan terjadinya komplikasi pada infeksi dengue. Oleh karena itu, peneliti tertarik untuk mencari tahu faktor apa saja yang dapat memengaruhi terjadinya komplikasi pada anak dengan infeksi dengue di RSUD Abdul Wahab Sjahranie Samarinda.

\section{Metode}

Rancangan penelitian ini adalah penelitian analitik observasional dengan desain cross sectional. Pengambilan sampel dilakukan dari data rekam medis pasien anak infeksi dengue di RSUD Abdul Wahab Sjaharanie, mulai dari Februari-Maret 2020. Pengambilan sampel dilakukan dengan menggunakan teknik purposive sampling, yaitu memilih sampel berdasarkan kriteria inklusi dan eksklusi yang telah ditentukan. Kriteria inklusi adalah anak usia 0-18 tahun yang terdiagnosis infeksi dengue berdasarkan rekam medis. Kriteria eksklusi adalah catatan rekam medis yang tidak lengkap, subjek penelitian yang sedang dalam kondisi sakit sebelum mendapatkan perawatan di rumah sakit, dan yang memiliki riwayat penyakit lainnya selama masa perawatan yang dapat menyebabkan trombositopenia. Penelitian ini telah memperoleh kelayakan etik dari Komite Etik Penelitian Kesehatan RSUD Abdul Wahab Sjahranie Samarinda.

Dilakukan pengambilan data dari rekam medis yang meliputi usia, jenis kelamin, berat badan, tinggi/ panjang badan, nilai trombosit, kadar hematokrit, status perdarahan, serta komplikasi. Data yang diambil tersebut dimasukkan ke dalam program perangkat lunak SPSS $^{\circledR}$ 25. Data dianalisis menggunakan uji Fisher Exact untuk menguji nilai trombosit dan Kruskal Wallis untuk menguji status gizi dan kadar hematokrit. Tingkat kemaknaan dalam penelitian ini dinyatakan bila $\mathrm{p}<0,05$.

\section{Hasil}

Subyek penelitian didapatkan 110 sampel yang memenuhi kriteria inklusi dari total 184 rekam medis yang dibuka. Berdasarkan status gizi, sampel lebih banyak memiliki gizi normal, yaitu $49(44,5 \%)$ dan 


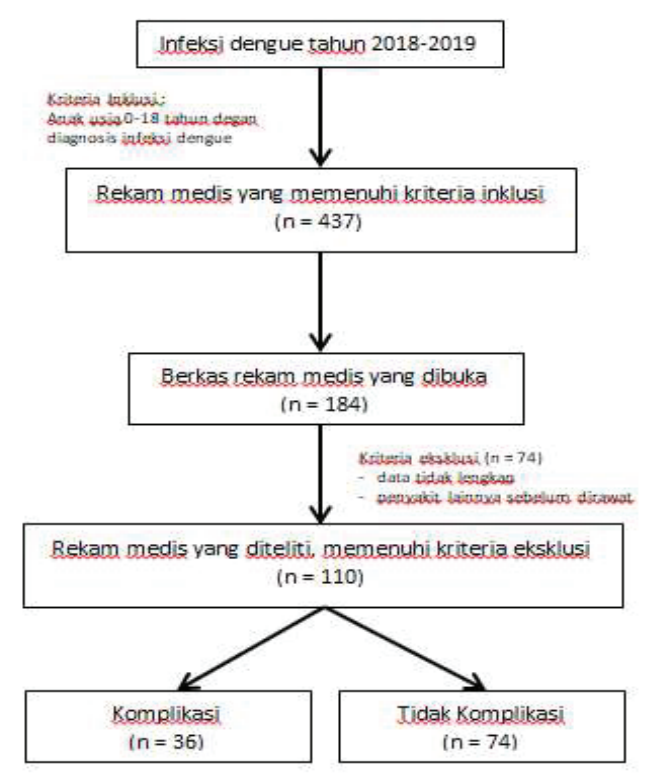

Gambar 1. Skema alur rekrutmen sampel paling sedikit dengan gizi buruk, yaitu $5(4,5 \%)$ orang. Sampel dengan peningkatan kadar hematokrit (>20\%) merupakan yang terbanyak, yaitu 48 (43,6\%). Sampel dengan nilai trombosit $\leq 5000074$ (67,3\%). Karakteristik sampel secara lengkap dari penelitian ini tertera pada Tabel 2.

Karakteristik yang berhubungan dengan terjadinya komplikasi pada anak dengan infeksi dengue adalah status gizi (OR 2,39), nilai trombosit $(\mathrm{OR} 6,09)$ dan kadar hematokrit (OR 2,48).

\section{Pembahasan}

Penelitian ini mendapatkan hasil bahwa terdapat hubungan antara status gizi dengan terjadinya komplikasi. Anak dengan gizi buruk/kurang serta gizi lebih berisiko 2,39 kali lebih besar untuk mengalami komplikasi dibanding anak dengan gizi normal. Anak dengan status gizi buruk hampir semuanya mengalami

Tabel 1. Karakteristik klinis sampel

\begin{tabular}{lccc}
\hline Karakteristik & $\begin{array}{c}\text { Komplikasi (\%) } \\
\mathrm{n}=36\end{array}$ & $\begin{array}{c}\text { Tidak Komplikasi (\%) } \\
\mathrm{n}=74\end{array}$ & $\begin{array}{c}\text { Total (\%) } \\
\mathrm{n}=110\end{array}$ \\
\hline $\begin{array}{l}\text { Usia (tahun) } \\
\leq 5\end{array}$ & $5(4,5)$ & $9(8,2)$ & \\
$>5$ & $31(28,2)$ & $65(59,1)$ & $14(12,7)$ \\
$\begin{array}{l}\text { Jenis kelamin } \\
\text { Laki-laki }\end{array}$ & & & $96(87,3)$ \\
Perempuan & $17(15,5)$ & $42(38,2)$ & $59(53,6)$ \\
\hline
\end{tabular}

Tabel 2. Variabel dan komplikasi

\begin{tabular}{|c|c|c|c|c|c|}
\hline Variabel & $\begin{array}{c}\text { Komplikasi } \\
\mathrm{n}=36\end{array}$ & $\begin{array}{c}\text { Tidak komplikasi } \\
\mathrm{n}=74\end{array}$ & $\begin{array}{c}\text { Total } \\
\mathrm{n}=110\end{array}$ & $\mathrm{p}$ & $\begin{array}{c}\text { OR } \\
\text { (Min-Maks) }\end{array}$ \\
\hline \multicolumn{6}{|l|}{ Status gizi, $(\%)^{* *}$} \\
\hline Buruk & $4(3,6)$ & $1(0,9)$ & $5(4,5)$ & 0,036 & \multirow{4}{*}{$\begin{array}{c}2,39 \\
(1,03-5,57)\end{array}$} \\
\hline Kurang & $0(9,1)$ & $13(11,8)$ & $23(20,9)$ & & \\
\hline Normal & $11(10)$ & $38(34,5)$ & $49(44,5)$ & & \\
\hline Lebih & $11(10)$ & $22(20)$ & $33(30)$ & & \\
\hline \multicolumn{6}{|l|}{ Nilai trombosit $(\%)^{*}$} \\
\hline$\leq 50.000$ & $32(29,1)$ & $42(38,2)$ & $74(67,3)$ & \multirow[t]{3}{*}{0,001} & 6,09 \\
\hline$>50.000$ & $4(3,6)$ & $32(29,1)$ & $36(32,7)$ & & $(1,95-$ \\
\hline Kadar hematokrit, $(\%)^{* *}$ & & & & & $18,99)$ \\
\hline Menurun & $1(0,9)$ & $8(7,3)$ & $9(8,2)$ & \multirow[t]{3}{*}{0,010} & 2,48 \\
\hline Normal & $12(10,9)$ & $41(37,3)$ & $53(48,2)$ & & $(1,08-5,70)$ \\
\hline Meningkat & $23(20,9)$ & $25(22,7)$ & $48(43,6)$ & & \\
\hline
\end{tabular}

" Analisis menggunakan Fisher Exact, oleh karena terdapat frekuensi harapan <5 pada salah satu sel

${ }^{* *}$ Analisis menggunakan uji Kruskal-Wallis, oleh karena kelompok $>2$ dan frekuensi harapan pada salah satu sel $<5$. 
komplikasi (4 dari 5 orang). Hal ini sesuai dengan penelitian sebelumnya, anak dengan status gizi buruk/ kurang memiliki risko 9,474 kali lebih besar untuk mengalami infeksi dengue. Status gizi kurang/buruk mempengaruhi imunitas. Hal ini dikarenakan anak dengan status gizi kurang memiliki imunitas seluler yang rendah sehingga rentan terhadap infeksi virus, termasuk virus dengue. ${ }^{13}$ Anak dengan status gizi tidak normal, yaitu gizi kurang ataupun lebih memiliki risiko 1,25 kali lebih besar untuk mengalami infeksi dengue dibanding anak dengan gizi normal. ${ }^{12}$

Gizi merupakan faktor penentu yang penting dari respon imun tubuh dan kekurangan gizi merupakan penyebab kurangnya kekebalan tubuh (immunodeficiency). Bukti menunjukkan bahwa pada saat kekurangan zat gizi mikro Zn, Se, Fe, Cu, vitamin A, C, E dan Vitamin B6 serta asam folat, berpengaruh penting terhadap respon imun. Defisiensi asam lemak dapat menyebabkan atropi limfoid dan penurunan respon antibodi terhadap antigen, penurunan kemampuan T-dependent dan T-independent. Sel $T$ sendiri berperan dalam respon imun seluler. Sel T spesifik untuk virus dengue dapat mengenali sel yang terinfeksi virus dengue dan menimbulkan respons beragam berupa proliferasi sel T, menghancurkan (lisis) sel terinfeksi dengue, serta memproduksi berbagai sitokin. ${ }^{16,17}$

Anak dengan status gizi lebih/gemuk memiliki risiko untuk mengalami keparahan infeksi dengue sebanyak 5,482 kali dibanding gizi baik. ${ }^{18}$ Seseorang dengan gizi lebih atau obesitas memiliki penumpukan jaringan lemak akibat peningkatan jumlah dan besar sel adiposit. Sel adiposit jaringan lemak putih mensekresikan sitokin pro-inflamasi TNF- $\alpha$ dan beberapa interleukin. Pada seseorang yang obesitas, terjadi peningkatan ekspresi TNF- $\alpha$ dan IL-6 yang dapat menyebabkan peningkatan permeabilitas vaskular dan pada akhirnya terjadi perburukan keadaan berupa syok. ${ }^{16,19}$

Penelitian ini mendapatkan hasil bahwa terdapat hubungan antara nilai trombosit dengan terjadinya komplikasi pada anak dengan infeksi dengue. Anak dengan nilai trombosit $\leq 50.000 / \mathrm{uL}$ berisiko 6,09 kali lebih besar untuk mengalami komplikasi dibanding anak dengan nilai trombosit lebih besar. Nilai trombosit $\leq 50.000 / \mathrm{uL}$ merupakan salah satu faktor prognosis terjadinya infeksi dengue yang lebih berat. ${ }^{14}$ Trombositopenia merupakan salah satu kelainan hematologis yang ditemukan pada hampir semua kasus infeksi dengue. Mekanisme yang dapat menyebabkan trombositopenia pada infeksi dengue adalah adanya supresi sumsum tulang serta destruksi dan pemendekan masa hidup trombosit. ${ }^{20}$ Anak dengan syok memiliki trombosit lebih rendah dibanding anak tanpa syok. Trombositopenia pada infeksi dengue dapat menyebabkan perdarahan. Perdarahan dapat menyebabkan manifestasi infeksi dengue yang lebih berat. Anak dengan syok memiliki trombosit lebih rendah dibanding anak tanpa syok. ${ }^{21}$

Penelitian ini mendapatkan hasil bahwa kadar hematokrit berhubungan dengan terjadinya komplikasi pada anak dengan infeksi dengue. Anak dengan kadar hematokrit tidak normal (menurun/meningkat) memiliki risiko 2,48 kali lebih besar untuk mengalami komplikasi dibanding anak dengan kadar hematokrit normal. Hematokrit $>45 \%$ merupakan salah satu faktor penyebab terjadinya keparahan berupa syok. ${ }^{14}$ Kadar hematokrit memiliki hubungan dengan korelasi positif terhadap derajat infeksi dengue, yang berarti semakin tinggi kadar hematokrit seseorang maka tingkat keparahan infeksi dengue akan semakin tinggi pula. ${ }^{22}$

Kenaikan hematokrit ( $\geq 20 \%)$ merupakan tanda indirek kebocoran plasma. Kebocoran plasma yang berat menimbulkan volume intravaskular berkurang yang akan menyebabkan terjadinya keparahan berupa syok dan dapat memperburuk prognosis. ${ }^{16}$

\section{Kesimpulan}

Status gizi, nilai trombosit $\leq 50.000$, dan kadar hematokrit meningkat memiliki hubungan yang signifikan terhadap terjadinya komplikasi pada anak dengan infeksi dengue.

\section{Daftar pustaka}

1. Centers for Disease Control and Prevention. Dengue and dengue hemorrhagic fever. U.S Department of Health and Human Services. 2009. Diunduh pada 4 November 2019. Didapat dari https://www.cdc.gov/dengue/resources/denguedhfinformation-for-health-care-practitioners_2009.pdf.

2. Soedarmo SP, Garna H, Hadinegoro S, Satari H, penyunting. Buku Ajar Infeksi dan Pediatri Tropis. Edisi Kedua. Jakarta: Badan Penerbit IDAI; 2015.h.156.

3. World Health Organization. Dengue guidelines for diagnosis, treatment, prevention and control, New Edition. 2009. Diunduh pada 4 November 2019. Didapat dari https://www. who.int/tdr/publications/documents/dengue-diagnosis.pdf.

4. World Health Organization. Dengue and severe dengue. 2021. Diunduh pada 27 November 2021. Didapat dari https://www. 
who.int/news-room/fact-sheets/detail/dengue-and-severe-dengue

5. Pan American Health Organization, World Health Organization. Epidemiological update dengue. 2020. Diunduh pada 27 November 2021. Didapat dari https://www. paho.org/sites/default/files/2020-02/2020-feb-7-phe-epi-updatedengue.pdf.

6. Fadilla A N, Husada D, Utomo B. Epidemiology of children with severe dengue infection in Dr. Soetomo General Hospital. J Indon Med Assoc 2020;70:41-7.

7. World Health Organization-Regional Office for South East Asian Region. SEARO Dengue Situation Update, 2012. Diunduh pada 4 November 2019. Didapat dari http:// www.searo.who.int/entity/vector_borne_tropical_diseases/datal seardengueupdate.pdf.

8. Kementerian Kesehatan Republik Indonesia. Situasi DBD di Indonesia. Jakarta: Kemenkes RI; 2016.

9. Dinas Kesehatan Provinsi Kalimantan Timur. Profil kesehatan tahun 2017. Samarinda: Depkes Kaltim; 2018.

10. Leovani V, Sembiring, LP, Winarto. Gambaran klinis dan komplikasi pasien demam berdarah dengue derajat III dan IV di bagian penyakit dalam RSUD Arifin Achmad Provinsi Riau Periode 1 Januari 2012 - 31 Desember 2013. JOM FK 2015;2:1-15.

11. Mihkael, K. Profil klinis komplikasi infeksi virus dengue pada bayi di instalasi rawat inap anak RSUD Dr. Soetomo tahun 2015-2016 (tesis). Surabaya: Universitas Airlangga, 2018.

12. Hakim L, Kusnandar AJ. Hubungan Status gizi dan kelompok umur dengan status infeksi virus dengue. Aspirator 2012;4:34-45.

13. Permatasari DY, Rumaningrum G, Novitasari A. Hubungan status gizi, umur, dan jenis kelamin dengan derajat infeksi dengue pada anak. Jurnal Kedokteran Muhammadiyah
2015;2:24-8.

14. Yulianto, A. Laksono, S. \& Jufrie, M. Faktor Prognosis Derajat Keparahan Infeksi Dengue. Sari Pediatri 2016;18:3:198-203.

15. RSUD Abdul Wahab Sjahranie. Profil 2017 RSUD Abdul Wahab Sjahranie Samarinda. 2017. Diunduh pada 19 Januari 2020. Didapat dari: http://www.rsudaws.co.id/uploads/ DOWNLOAD/Profil\%20RSUD\%20AWS\%202017.pdf.

16. Hadinegoro SR, Moedjito I, Chairulfatah A, penyunting. Pedoman diagnosis dan tatalaksana infeksi virus dengue pada anak. Jakarta: UKK Infeksi dan Penyakit Tropis IDAI; 2014.

17. Food Technology BINUS University. Fungsi Zat Gizi terhadap Imunitas Tubuh. 2015. Diakses pada 25 Juni 2020. Didapat dari https://foodtech.binus.ac.id/2015/10/09/fungsi-zat-giziterhadap-imunitas-tubuh-2/.

18. Utomo WC. Hubungan status gizi terhadap derajat keparahan demam berdarah dengue pada anak usia 0-14 tahun periode Januari Desember 2016 di RS PKU Muhammadiyah Yogyakarta (skripsi). Yogyakarta: Fakultas Kedokteran Universitas Islam Indonesia, 2016.

19. Buntubatu S, Arguni E, Indrawanti R, Laksono IS, Prawirohartono EP. Status Nutrisi sebagai faktor risiko sindrom syok dengue. Sari Pediatri 2016;18:3:226-32.

20. Setiati S, Alwi I, Sudoyo AW, dkk. Buku ajar ilmu penyakit dalam Jilid I. Edisi VI. Jakarta: Interna Publishing; 2015.

21. Heatubun CE, Umboh A, Mongan AE, Manoppo F. Perbandingan jumlah trombosit pada demam berdarah dengue tanpa syok dan syok di RSUP Prof. Dr. R. D. Kandou Manado. Jurnal e-Biomedik (eBM) 2013;1:2:863-7.

22. Towidjojo VD, Tandungan N. Hubungan kadar trombosit dan hematokrit dengan derajat keparahan demam berdarah dengue pada pasien dewasa. Jurnal Ilmiah Kedokt 2014;1:2:26-35. 